\title{
Effects of Sodium Depletion on Contractions Evoked in Intact and Skinned Muscles of the Guinea-pig Mesenteric Artery
}

\author{
Takeo IтоH, Hikaru Suzuki, and Hirosi KuriYama \\ Department of Pharmacology, Faculty of Medicine, \\ Kyushu University, Fukuoka, 812 Japan
}

\begin{abstract}
In the guinea-pig mesenteric artery, reduction in $[\mathrm{Na}]_{\circ}$ by $30 \mathrm{~mm}$ (substituted by choline or sucrose; $137 \mathrm{~mm}[\mathrm{Na}]_{\mathrm{o}}$ in Krebs solution) generated contraction with no change in membrane potential. In $\mathrm{NaCl}$ free solution $\left(15 \mathrm{~mm}[\mathrm{Na}]_{\mathrm{o}}\right)$, the amplitude of phasic contraction reached 0.8 times the contraction evoked by $118 \mathrm{~mm}[\mathrm{~K}]_{\text {o }}$ with only a slight depolarization. In $\mathrm{NaCl}$-free solution, the amplitude of phasic contraction evoked by noradrenaline (NA) $5 \times 10^{-5} \mathrm{M}$ or caffeine $5 \mathrm{~mm}$ increased to roughly twice the amplitude of the contraction evoked in the control solution. In $\mathrm{Ca}$-free solution, the $\mathrm{K}$-, $\mathrm{NaCl}$-free- or $\mathrm{Na}$-free-induced contractions rapidly ceased, but NA-induced contraction ceased within $5 \mathrm{~min}$ and the caffeine-induced contraction persisted for more than $15 \mathrm{~min}$. In a skinned fiber, increase of $[\mathrm{Na}]_{0}$ from 10 to $60 \mathrm{~mm}$ suppressed the $\mathrm{pCa}$-tension relationship in the ranges of $10^{-7}$ and $10^{-5} \mathrm{M}$ free $\mathrm{Ca}$ but not with a dose of $30 \mathrm{~mm}[\mathrm{Na}]_{0}$. NA $\left(10^{-5} \mathrm{M}\right)$ had no effect on skinned fibers. Increase in $\mathrm{Na}$ concentration $(60 \mathrm{~mm})$ had no effect on $\mathrm{Ca}$ accumulation in the store site or on Ca release by caffeine. Possible Na-related mechanisms on the development of mechanical response are discussed in relation to $\mathrm{Ca}$ on the surface and in the internal membrane structure. The $\mathrm{NaCl}$ free-induced contraction in smooth muscles of the guinea-pig mesenteric artery is postulated to be due to influx of $\mathrm{Ca}$ through the $\mathrm{Na}$ channel, rather than the $\mathrm{Ca}$ channel.
\end{abstract}

The removal of $\mathrm{Na}$ from the bathing solution produces changes in the tone of vascular smooth muscles. In the rabbit pulmonary artery, Na-free solution produces a contraction, while a relaxation occurs in the porcine coronary artery (CASTEELs et al., 1977; HiRATA et al., 1980). Such regional and species differences in the mechanical response in various visceral muscles are commonly observed. The effects of $\mathrm{Na}$ removal are mainly considered to be related to changes in the intracellular free $\mathrm{Ca}$ following changes in the $\mathrm{Ca}$ flux at the surface membrane or release of the stored Ca (Katase and Tomita, 1972; Blaustein, 1977; Friedman, 1977; Van Breemen et al., 1978; Droogmans and CaSteels, 1979; Bolton, 1979; Brading et al., 1980).

Received for publication March 18, 1981

伊藤猛雄，鈴木 光，栗山 熙 
BRADING et al. (1980) observed the effects of Na removal on the carbacholinduced contraction in the guinea-pig taenia coli and discussed the important role of $\mathrm{Ca}$ stores in the production of contraction under conditions of low $[\mathrm{Na}]_{\mathrm{i}}$. They stated that $\mathrm{Na}$ removal inhibits utilization of these sources of $\mathrm{Ca}$ : removal

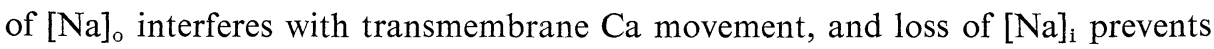
refilling of the internal $\mathrm{Ca}$ store. On the contrary, in the mesenteric artery, removal or reduction of $[\mathrm{Na}]_{0}$ generates the contraction and enhances the contraction produced by caffeine or noradrenaline (NA). These findings suggest that the properties of the $\mathrm{Ca}$ store site differ with the tissue.

We examined the effects of $\mathrm{Na}$ removal on the mechanical response evoked by excess $[\mathrm{K}]_{\mathrm{o}}$, caffeine, or NA in intact and chemically skinned fibers of the guinea-pig mesenteric artery. This tissue was selected because: i) we have already assessed the passive membrane property (KuRIYAMA and SUZUKI, 1981), ii) this muscle cell does not generate spontaneous spikes and the spike is evoked only by nerve-mediated or direct muscle stimulation, i.e., the factor modifying the generation of contraction by Ca-current is deleted in the resting membrane potential, and iii) the chemical skinning method using saponin is applicable to this preparation (Iтон et al., 1981). The possible role of the Ca store site and the $\mathrm{Ca}$ flux in modifying the contraction-relaxation mechanism in relation to $[\mathrm{Na}]_{i}$ and $[\mathrm{Na}]_{\mathrm{o}}$ is discussed.

\section{METHOD}

Materials. Guinea-pigs of either sex were stunned and bled. The dissected mesenteric artery from the jejunum region was about $10 \mathrm{~mm}$ in length and about $0.1-0.12 \mathrm{~mm}$ in diameter. For tension recording from the chemically skinned muscle cells, the vessel was carefully teased apart using jewellers' forceps, cut along the longitudinal direction, and circularly cut strips of $0.1 \mathrm{~mm}$ in width and $0.3 \mathrm{~mm}$ in length were prepared. The preparation was set up in a small chamber with a capacity of $0.9 \mathrm{ml}$ through which the test solution was superfused rapidly by jetting from one end and by sucking off simultaneously with a water pump from the other end. Both ends of the preparation were fixed between pieces of Scotch double-stick tape (3M Co., St. Paul, Minn.), and isometric tension was recorded using a strain gauge transducer (U-gauge, Shinko Co.).

For tension recording from the intact tissue, the tissue was prepared the same way as were the skinned preparations. For the membrane potential change, the length and diameter of the preparation were about 10 and $0.1 \mathrm{~mm}$ (without dissection), respectively, and superfusion was carried out at a rate of $3 \mathrm{ml} / \mathrm{min}$ in a 2-ml organ bath.

Procedures. The experimental procedures were similar to those described by Ітон et al. (1981). Tension recording from the skinned muscle preparation: The tissue was superfused with modified Krebs solution of the following composi- 
tion (mM: BüLbring, 1954); $\mathrm{Na}^{+} 137.4, \mathrm{~K}^{+}$5.9, $\mathrm{Mg}^{2+} 2.5, \mathrm{Cl}^{-}$134.0, $\mathrm{H}_{2} \mathrm{PO}_{4}^{-}$ $1.2, \mathrm{HCO}_{3}-15.5$, and glucose 11.5 , and then replaced with $118 \mathrm{~mm}[\mathrm{~K}]_{0}$ containing solution in which the $\mathrm{NaCl}$ was replaced with $\mathrm{KCl}$ isosmotically. After recording the $\mathrm{K}$-induced contraction, the solution was replaced with relaxing solution containing $130 \mathrm{~mm} \mathrm{KCl}, 20 \mathrm{~mm}$ Tris-maleate, $5 \mathrm{~mm} \mathrm{MgCl}_{2}, 5 \mathrm{~mm} \mathrm{ATP}$, and $4 \mathrm{~mm}$ EGTA at pH $6.8(10 \mathrm{~mm} \mathrm{Na}$ remained as ATP salt). Saponin treatment was then carried out by leaving the preparation for $20 \mathrm{~min}$ in the relaxing solution containing $50 \mu \mathrm{g} / \mathrm{ml}$ saponin (ICN). The preparation was washed again with the same solution and left until the tension level became constant at about zero level. To obtain caffeine-induced contraction, the concentration of EGTA was reduced to $10^{-4} \mathrm{M}$ throughout the experiment. The $\mathrm{pH}$ of the caffeine-containing solution was kept at 6.8 by adding $\mathrm{KOH}$ instead of $\mathrm{KCl}$ to the relaxing solution.

Various $\mathrm{Ca}$ concentrations were prepared by adding an appropriate amount of $\mathrm{CaCl}_{2}$ to EGTA. The apparent binding constant of EGTA for Ca was considered to be $10^{6} \mathrm{M}^{-1}$, at $\mathrm{pH}$ 6.8. To determine the binding constant of ATP for $\mathrm{Mg}$ at pH $6.8\left(4 \times 10^{3} \mathrm{M}^{-1}\right)$, we used the value calculated by MARTELL and SChWARZENBACH (1956) as reported by SAIDA and NonOMURA (1978), and the free $\mathrm{Mg}$ concentration was kept at $1 \mathrm{mM}$.

$\mathrm{Na}$-deficient or $\mathrm{Na}$-free solution was prepared by replacement of $\mathrm{Na}$ with choline or sucrose and the $\mathrm{pH}$ of the solution was adjusted to 7.2 with Tris-buffer. For the choline solution, $10^{-6} \mathrm{~g} / \mathrm{ml}$ atropine was added to suppress the muscarinic action in most experiments.

Tension recording from the intact muscle preparation: Preparation similar to that used for the skinned muscle tissue was superfused in Krebs solution, and various concentrations of excess K-solution, caffeine, or NA were applied.

The microelectrode method: The glass capillary of the electrode was filled with $3 \mathrm{MKCl}$, and the resistance was $60-80 \mathrm{M} \Omega$. The measured membrane potential was expressed as mean \pm S.D.

The following drugs were used; $d$, l-noradrenaline- $\mathrm{HCl}$, caffeine, ethyleneglycol-bis( $\beta$-aminoethylether)- $N, N^{\prime}$-tetraacetic acid (EGTA). The stock solution for drugs was freshly prepared just before each experiment.

\section{RESULTS}

Effects of Na removal on the membrane potential and mechanical response

Effects of Na-deficient solution on membrane potential and mechanical response were observed. In $15.5 \mathrm{~mm}[\mathrm{Na}]_{\mathrm{o}}$, prepared by replacement with choline, the membrane potential was slightly reduced (in the control, the membrane potential was $-67.2 \pm 2.8 \mathrm{mV}, n=20$, which depolarized to $-60.1 \pm 3.4 \mathrm{mV}, n=20$ in $15.5 \mathrm{~mm} \mathrm{Na}$ at about $10 \mathrm{~min}$ exposure), and a large contraction which then relaxed to a certain level (phasic and tonic contraction) was evoked. 
Figure 1A shows the effects of $\mathrm{NaCl}$-free solution (15.5 mM Na as $\mathrm{NaHCO}_{3}$ ) on the membrane potential. $\mathrm{NaCl}$-free solution was prepared by choline- $\mathrm{Cl}$, choline- $\mathrm{Cl}$ with atropine $\left(10^{-6} \mathrm{~g} / \mathrm{ml}\right)$ or sucrose. To avoid factors introduced by the liquid junction potential, the microelectrode was repetitively inserted into the cell after adjustment of the zero level. Replacement of $\mathrm{NaCl}$ with choline produced a transient hyperpolarization of the membrane but the level returned to control level within a few min and then the membrane slightly depolarized. With the simultaneous application of choline and atropine, no such hyperpolarization was observed, and the depolarization appeared. On the other hand, by replacement with sucrose, the membrane was rapidly depolarized and a rather large depolarization level (about $-60 \mathrm{mV}$ ) was sustained compared to that produced by choline. In this figure, the effects of $\mathrm{NaCl}$-free solution were observed only at 5 min exposure in $\mathrm{NaCl}$-free solution. However, when the tissue was exposed for more than $10 \mathrm{~min}$, the membrane potential measured in choline or sucrose solution showed much the same value, i.e., the membrane depolarized by sucrose solution repolarized to the level of the choline-induced depolarization.

When the $[\mathrm{Na}]_{\text {。 }}$ was reduced to half $(69 \mathrm{~mm} \mathrm{Na})$ that in the control solution, the membrane potential was similar to that observed in the control solution $(-67.2$ $\pm 2.8 \mathrm{mV}, n=20$ in $137 \mathrm{~mm}$ vs. $-66.3 \pm 1.9 \mathrm{mV}, n=20$ in $69 \mathrm{~mm}$ at about $10 \mathrm{~min}$ exposure). However, in the case of the mechanical response, the minimum extent of $\mathrm{Na}$ depletion required to produce the contraction was $30 \mathrm{~mm}$, i.e., even in the presence of $107 \mathrm{~mm}[\mathrm{Na}]_{\text {。 }}$ the contraction was generated. Figure 1B shows the effects of various concentrations of $[\mathrm{Na}]_{0}$ replaced with choline on the membrane and mechanical responses. The membrane potential was measured during 10-15 min exposure and the maximum amplitude of phasic contraction was measured. Without any marked change in the membrane potential, the amplitude of contraction increased in proportion to the reduction in the $[\mathrm{Na}]_{\mathrm{o}}$ in the ranges of 30 and $137 \mathrm{~mm}[\mathrm{Na}]_{0}$. The amplitude of contraction recorded in the case of $118 \mathrm{~mm}$ $[\mathrm{K}]_{\circ}$ was registered in the figure as a relative tension of 1.0. In the Na-free solution, the membrane was significantly depolarized $(-52.1 \pm 4.2 \mathrm{mV}, n=15$ about $10 \mathrm{~min}$ exposure), and the contraction reached 0.82 times that evoked by $118 \mathrm{~mm}$ $[\mathrm{K}]_{0}$. The membrane potential observed in $2.5 \mathrm{~mm}[\mathrm{Na}]_{0}$ and Na-free solution significantly differed $(p<0.01, t$-test), while the amplitude of the contraction was similar in both solutions.

Figure 2A shows the relationship between membrane potential and contraction with various concentrations of $[\mathrm{K}]_{0}$. The contraction was evoked by depolarization of the membrane from $-69.2 \pm 2.3 \mathrm{mV}(n=15)$ to $-61.6 \pm 2.9 \mathrm{mV}$ $(n=15)$, i.e., when the $[\mathrm{K}]_{\text {。 }}$ was increased from 5.9 to $11.8 \mathrm{~mm},[\mathrm{Na}]_{\circ}$ was reduced conversely from 137 to $131 \mathrm{~mm}$.

Figure 2B summarizes the effects on the mechanical response of Na-deficient solution prepared by replacing $\mathrm{Na}$ with choline, sucrose or $\mathrm{K}$. The contraction evoked by $118 \mathrm{~mm}[\mathrm{~K}]_{\text {。 }}$ was registered as a relative tension of 1.0 . 


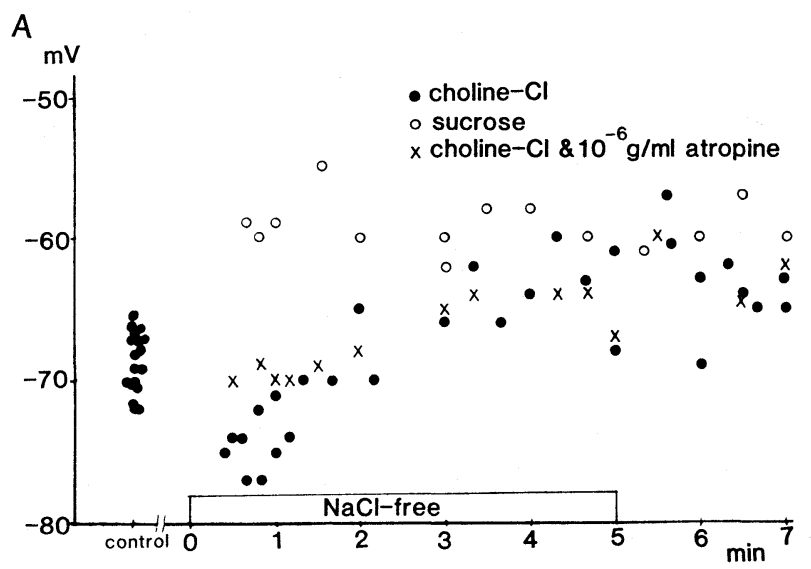

B

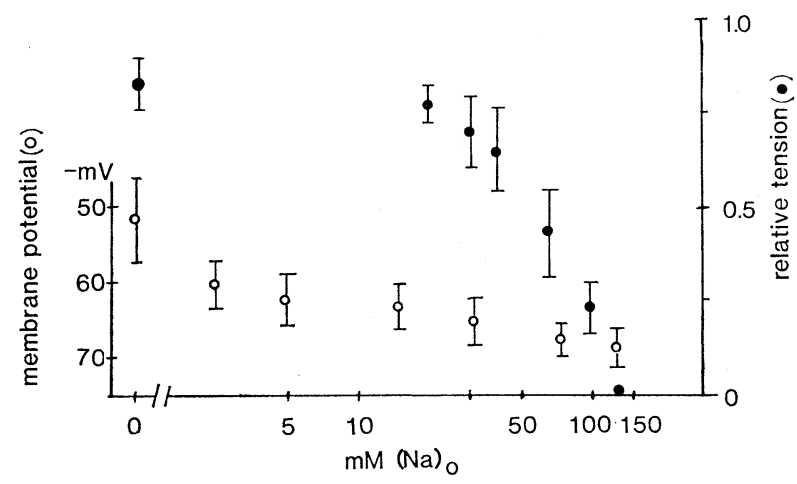

Fig. 1. A. Effects of $\mathrm{NaCl}$ replacement with choline or sucrose on membrane potential of guinea-pig mesenteric artery. $\mathrm{NaCl}$-free solution was applied for $5 \mathrm{~min}$. To measure the membrane potential, the microelectrode was successively inserted after adjustment of the zero potential level. B. Relationship between the membrane potential and mechanical responses in the various concentration of $[\mathrm{Na}]_{0}$. The contraction evoked by 118 $\mathrm{mM}[\mathrm{K}]_{\mathrm{o}}$ was registered as a relative tension of 1.0. Na was replaced with choline.

\section{Effects of Na-deficient solution on the caffeine-, NA- or K-induced contraction}

The contraction evoked by excess $[\mathrm{K}]_{\mathrm{o}}$, NA, or Na-deficient solution was composed of phasic and tonic components, i.e., with application of these agents, the rapidly developing phasic contraction declined to a certain sustained tonic level.

Figure $3 \mathrm{~A}$ shows the effects of caffeine on the mechanical response before, during and after application of $\mathrm{NaCl}$-free solution (15 mM Na). Caffeine (5 mM) produced a similar amplitude of phasic contraction as that evoked by $\mathrm{NaCl}$-free 
A

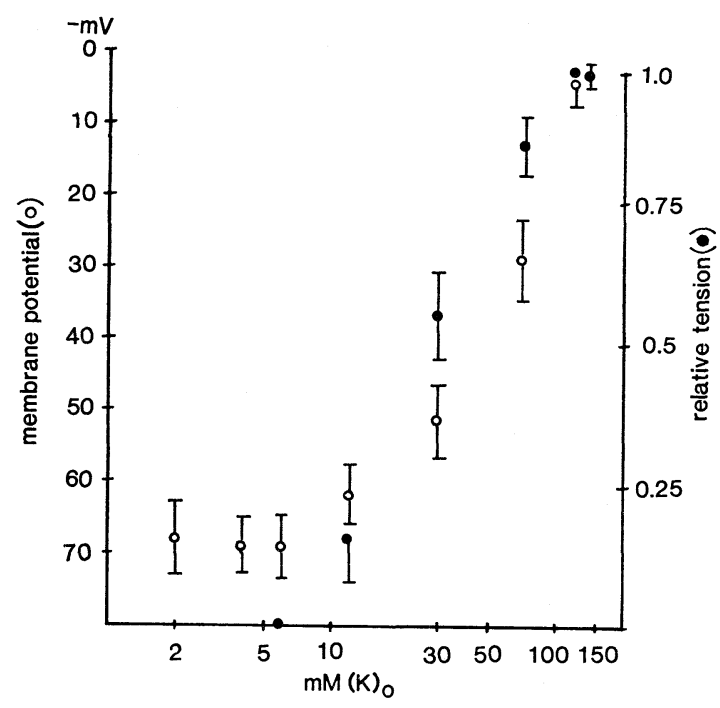

B

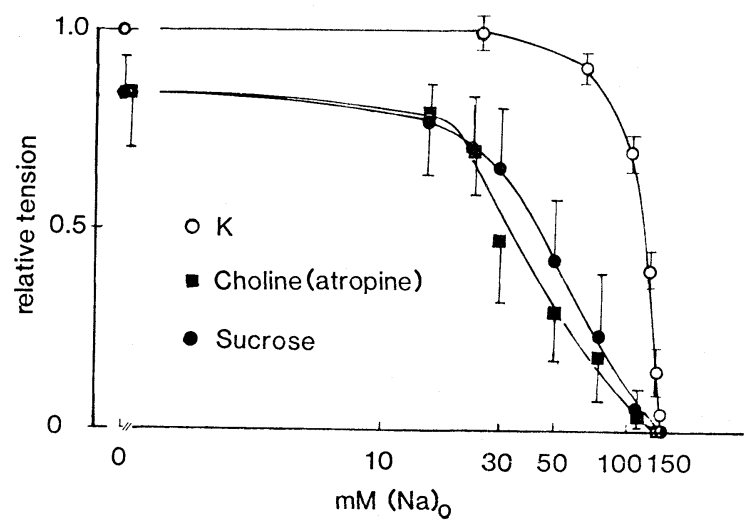

Fig. 2. A. Relationship between the membrane potential and mechanical responses in various concentrations of $[\mathrm{K}]_{0}$. The $118 \mathrm{~mm} \mathrm{~K}$-induced contraction was registered as a relative tension of 1.0. In A and B, vertical bars indicate $2 \times$ S.D. $(n=15-50$ for the membrane potential and $n=4-7$ for the mechanical response). B. Relationship between the mechanical responses and various concentrations of $[\mathrm{Na}]_{0}$. Na was substituted by either $\mathrm{K}$, choline or sucrose. In the solution containing choline, $10^{-6} \mathrm{~g} / \mathrm{ml}$ atropine was added. Vertical bars indicate S.D. or $2 \times$ S.D.

solution. When $5 \mathrm{~mm}$ caffeine was applied in the $\mathrm{NaCl}$-free solution, a much larger amplitude of contraction was evoked (1.8 times the control, $n=5$ after 20 min exposure). The caffeine-induced contraction was completely restored after the 
tissue had been rinsed with Krebs solution. A similar enhancement by caffeine in $\mathrm{NaCl}$-free solution was also observed by application of $10^{-5} \mathrm{M}$ NA (Fig. 3B). The NA-induced contraction in Krebs solution was much smaller (0.28 times, $n=$ 4) than that evoked by $5 \mathrm{~mm}$ caffeine or $\mathrm{NaCl}$-free solution. $\mathrm{NA}\left(10^{-5} \mathrm{M}\right)$ produced an enlarged contraction in $\mathrm{NaCl}$-free solution (2.0 times the control after $20 \mathrm{~min}$ exposure; $n=4$ ). With over $30 \mathrm{~min}$ exposure to the $\mathrm{NaCl}$-free solution, the amplitude of NA-induced contraction was only slightly reduced (1.7 times the control, $n=4$ ) but it was still much higher than that in the control. Differences between the NA- and caffeine-induced contractions in $\mathrm{NaCl}$-free solution were observed in the recovery from $\mathrm{NaCl}$-free solution, i.e., the caffeine-induced contraction rapidly returned to the control value, but the NA-induced contraction became rapidly much smaller than the control in Krebs solution (within $5 \mathrm{~min}$ ). Over $30 \mathrm{~min}$ was required for recovery to the control level.

When $\mathrm{NaCl}$-free solution was applied following pretreatment with $118 \mathrm{~mm}$ $[\mathrm{K}]_{0}$, the tonic contraction produced by excess $[\mathrm{K}]_{\mathrm{o}}$ was maintained at a similar amplitude, however, no phasic contraction was evoked (Fig. 3C). By the reversed sequence, excess $[\mathrm{K}]_{\mathrm{o}}$ produced a phasic contraction during generation of the tonic contraction evoked by $\mathrm{NaCl}$-free solution, and repetitively applied excess $[\mathrm{K}]_{\text {o }}$ in the $\mathrm{NaCl}$-free solution produced a similar amplitude of phasic contractions (Fig. $3 \mathrm{C})$.

These results suggest that $\mathrm{NaCl}$-free solution consistently increases the amplitude of caffeine- or NA-induced contraction and affects to some extent the Kinduced contraction.

Figure 4 shows the caffeine- and NA-induced contractions in the Ca-free solution. In the $\mathrm{NaCl}$-free solution, the caffeine- or caffeine with $122 \mathrm{~mm}[\mathrm{~K}]_{0}$ induced contraction was enhanced to a greater extent than the contraction evoked by caffeine alone. When effects of these procedures were observed in $\mathrm{Ca}$-free ( 2 mM EGTA) solution, the amplitude of phasic contraction evoked by caffeine $(5 \mathrm{~mm})$, caffeine $(5 \mathrm{~mm})$ with $\mathrm{NaCl}$-free or caffeine $(5 \mathrm{~mm})$ with $122 \mathrm{~mm}[\mathrm{~K}]_{\text {。 }}$ solution was decreased. The contraction evoked by $10^{-5} \mathrm{M}$ NA ceased within $5 \mathrm{~min}$. The amplitudes of the phasic contraction evoked by caffeine, caffeine with $\mathrm{NaCl}$ free solution, and caffeine with $122 \mathrm{~mm}[\mathrm{~K}]$ 。 solution differed in the Ca-containing solution, but the relative amplitudes of phasic contraction became similar after 5 min exposure in $\mathrm{Ca}$-free solution. In Ca-free solution, the contraction evoked by $122 \mathrm{~mm}[\mathrm{~K}]_{\text {。 }}$ or $\mathrm{NaCl}$-free solution ceased within $1 \mathrm{~min}$. These results indicate that, in the mesenteric artery, $122 \mathrm{~mm}[\mathrm{~K}]_{0}$ and $\mathrm{NaCl}$-free solution increase the $\mathrm{Ca}$ influx, and $10^{-5} \mathrm{M} \mathrm{NA}$, in part, releases the $\mathrm{Ca}$ stored in the cells as does caffeine.

\section{Effects of $\mathrm{Na}$ on chemically skinned muscles}

The chemically skinned muscles were prepared by addition of $50 \mu \mathrm{g} / \mathrm{ml}$ saponin to the relaxing solution for $20 \mathrm{~min}$. The criteria for the chemically skinned 
A

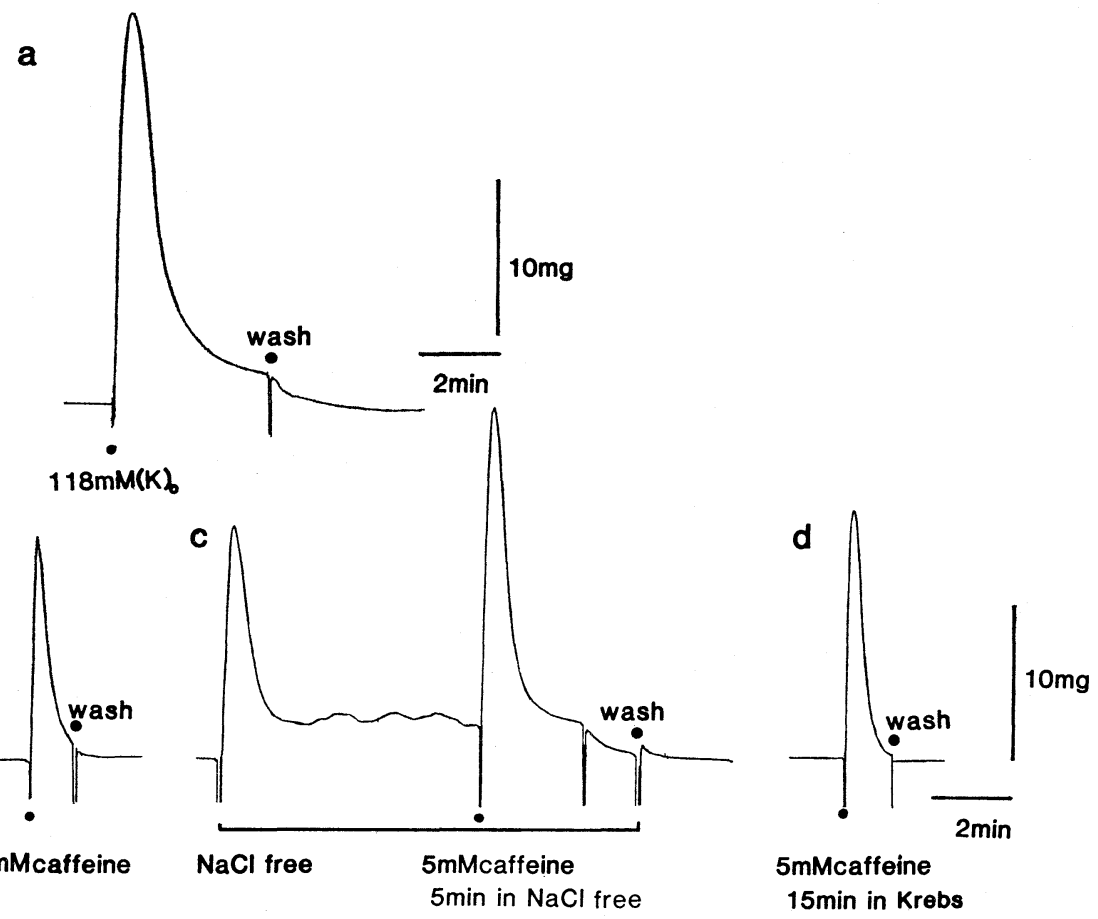

Fig. 3A.

B

a

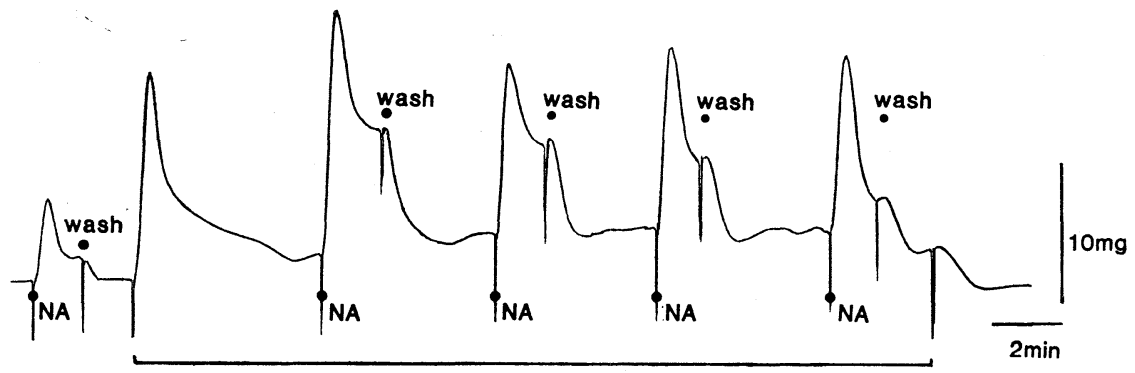

$\mathrm{NaCl}$ free

b

after washing
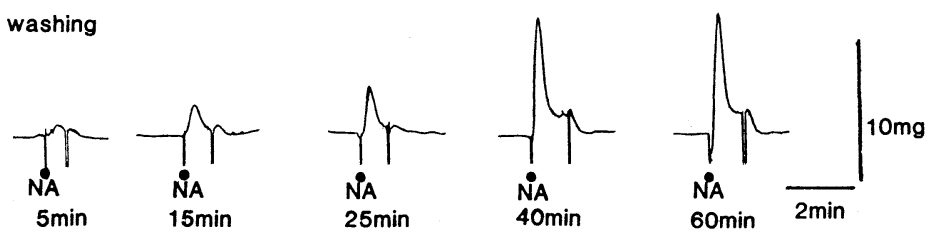

Fig. 3B. 

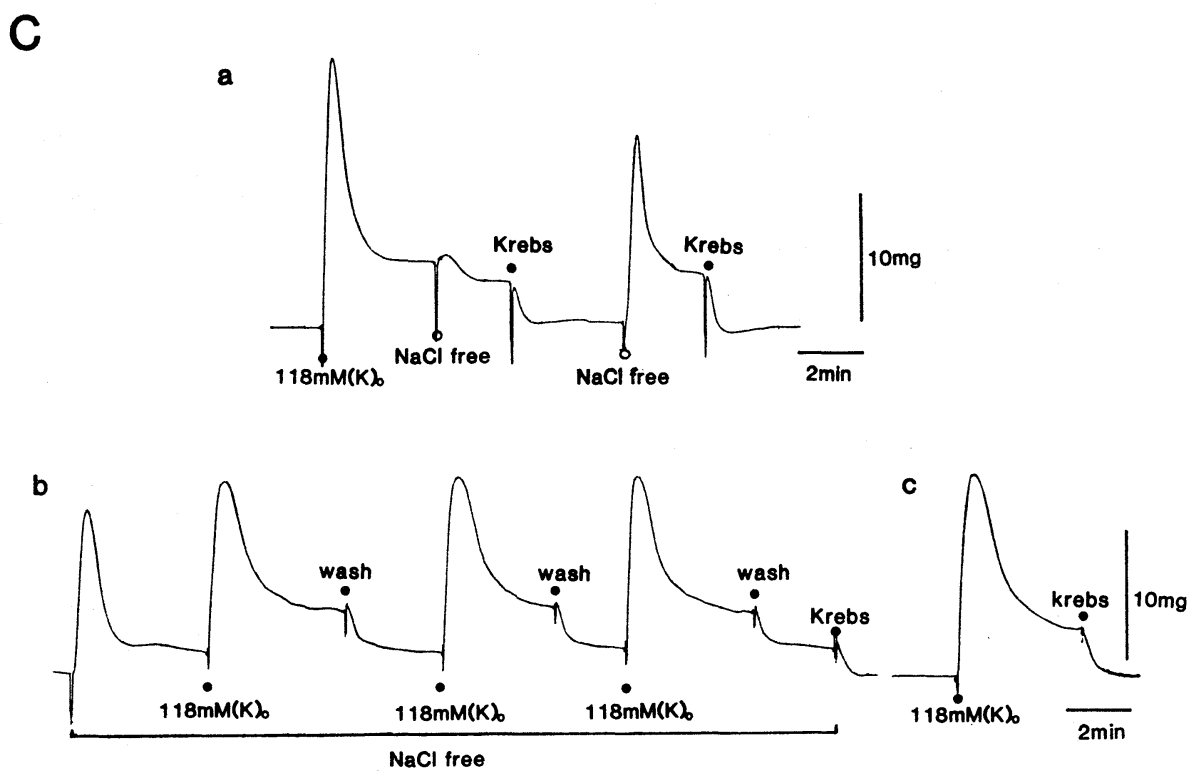

Fig. 3C.

Fig. 3. A. Effects of $5 \mathrm{~mm}$ caffeine on the mechanical response before, during and after application of $\mathrm{NaCl}$-free solution. As a control, $118 \mathrm{~mm}[\mathrm{~K}]$ o was applied (a). B. Effects of noradrenaline on the mechanical response evoked before, during and after application of $\mathrm{NaCl}$-free solution. a, before and during application of $\mathrm{NaCl}$-free solution, noradrenaline (NA: $10^{-5} \mathrm{M}$ ) was successively applied; $b$, effects of noradrenaline (NA: $10^{-5} \mathrm{M}$ ) on the mechanical response after pretreatment with $\mathrm{NaCl}$-free solution. C. Effects of 118 $\mathrm{mm}[\mathrm{K}]_{\mathrm{o}}$ solution on the mechanical response before, during and after application of $\mathrm{NaCl}-$ free solution. In a, $\mathrm{NaCl}$-free solution was successively applied after application of 118 $\mathrm{mm}[\mathrm{K}]_{\mathrm{o}}$ solution.

fiber preparation were the same as that described by Ітон et al. (1981), i.e., the amplitude of contraction evoked by $10^{-5} \mathrm{M}$ free $\mathrm{Ca}$ in skinned fibers was larger than that evoked by $118 \mathrm{~mm}[\mathrm{~K}]_{0}$ in intact muscle cells.

Figure $5 \mathrm{~A}$ shows the relationship between $\mathrm{pCa}$ and tension recorded from skinned muscles of the mesenteric artery. In the relaxing solution, $10 \mathrm{~mm} \mathrm{Na}$ was in the form of a salt of $\mathrm{Na}_{2}$-ATP, and the effects of $30 \mathrm{~mm} \mathrm{Na-}$ or $60 \mathrm{~mm} \mathrm{Na}-$ containing relaxing solution on the $\mathrm{Ca}$-induced contraction were compared with the control $(10 \mathrm{~mm} \mathrm{Na})$ relaxing solution. The amplitude of contraction was measured in response to cumulatively applied various concentrations of free $\mathrm{Ca}$. The minimum concentration of $\mathrm{Ca}$ required to produce a contraction was just above the concentration of $10^{-7} \mathrm{M}$, and $3 \times 10^{-7} \mathrm{M}$ Ca produced a markedly developed contraction. Maximum tension was induced by $10^{-5} \mathrm{M} \mathrm{Ca}$. By addition of $20 \mathrm{~mm} \mathrm{Na}$ (total $30 \mathrm{~mm} \mathrm{Na}$ ) the pCa-tension relationship was not markedly modified in comparison to that observed in $10 \mathrm{~mm} \mathrm{Na}$.

When $50 \mathrm{~mm} \mathrm{Na}$ was added (total $60 \mathrm{~mm}$ ), the amplitude of contraction evoked 


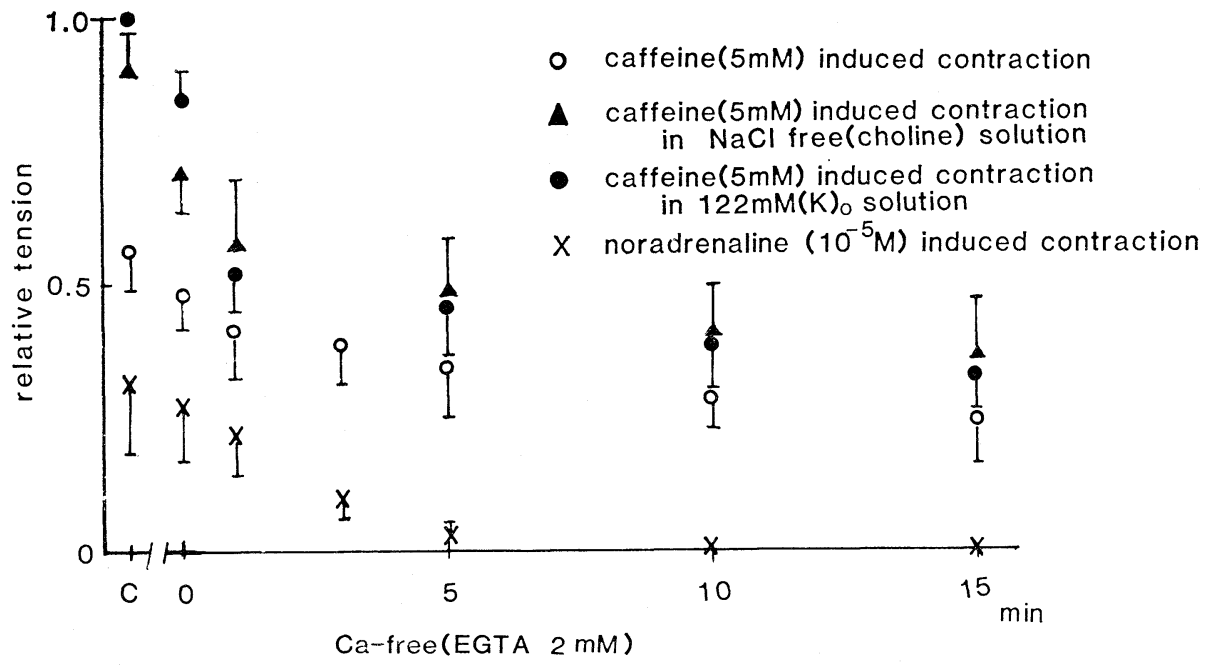

Fig. 4. Effects of Ca-free (EGTA) solution on the mechanical response evoked by caffeine, caffeine with $\mathrm{NaCl}$-free, caffeine with $122 \mathrm{~mm}[\mathrm{~K}]_{0}$ or noradrenaline $(n=4-8)$. C: control $(2.5 \mathrm{~mm} \mathrm{Ca})$. The amplitude of contraction evoked by caffeine with $122 \mathrm{~mm}[\mathrm{~K}]_{\mathrm{o}}$ solution was registered as a relative tension of 1.0. In a series of experiments, the individual test solution was applied after 20 min superfusion with Krebs solution.

by less than $10^{-5} \mathrm{M}$ Ca was suppressed, and this suppression was even more dominant in incubation media containing lower concentrations of $\mathrm{Ca}$. However, the suppression was smaller in cases where the contraction was evoked in the presence of $2 \mathrm{~mm}$ free $\mathrm{Mg}$ solution (control; $1 \mathrm{~mm}$ ). As shown in Fig. 5A, $2 \mathrm{~mm}$ free $\mathrm{Mg}$-containing relaxing solution consistently suppressed the Ca-induced contraction in all ranges of $\mathrm{Ca}$ concentration from $10^{-7}$ to $10^{-4} \mathrm{M}$. Figure $5 \mathrm{~B}$ shows a typical example of contractions evoked by various concentrations of $\mathrm{Ca}$ cumulatively applied to skinned muscles. As the control, $118 \mathrm{~mm}[\mathrm{~K}]_{0}$-induced contraction in intact muscle tissue was observed. After treatment with saponin in the relaxing solution, application of $3 \times 10^{-7} \mathrm{M}$ Ca produced a contraction and during this application, an additional $50 \mathrm{~mm} \mathrm{Na}$ replacing $\mathrm{K}$ suppressed the contraction to some extent. A similar suppression was also observed in the presence of $3 \times 10^{-6} \mathrm{M} \mathrm{Ca}$. Application of $3 \times 10^{-6} \mathrm{M}$ Ca to the relaxing solution produced a larger contraction than that evoked by $118 \mathrm{~mm}[\mathrm{~K}]_{\mathrm{o}}$ in the intact muscle cell. When the application procedure of excess $\mathrm{Na}$ was reversed, $i$ e., when $10 \mathrm{~mm} \mathrm{Na}$ containing solution was applied following pretreatment with $60 \mathrm{~mm}$ Na-containing solution in the presence of $\mathrm{Ca}$, the amplitude of $\mathrm{Ca}$-induced contraction increased.

These results indicate that the $\mathrm{Ca}$ receptor in the contractile protein is slightly suppressed by excess $\mathrm{Na}$ in the presence of relatively low concentrations of free $\mathrm{Ca}$, i.e., lowering the external $\mathrm{Na}$ enhanced the sensitivity of the $\mathrm{Ca}$ receptor.

Since $\mathrm{K}_{2}$-ATP is a labile compound, experiments on the effect of less than 10 $\mathrm{mm} \mathrm{Na}$ on the $\mathrm{pCa}$-tension relationship were not done. 
A

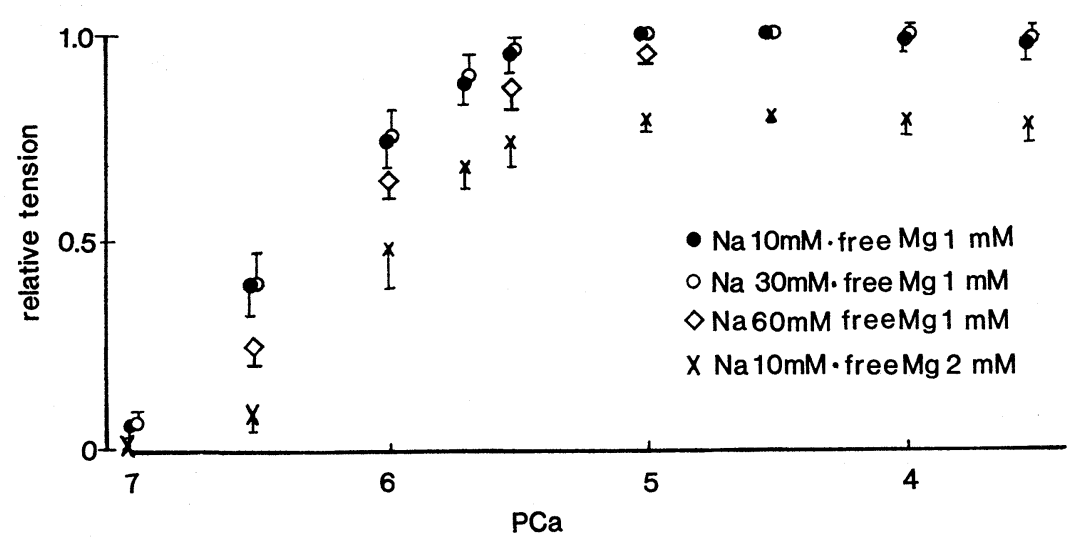

B

a

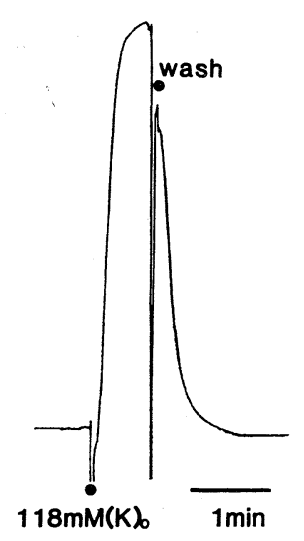

b

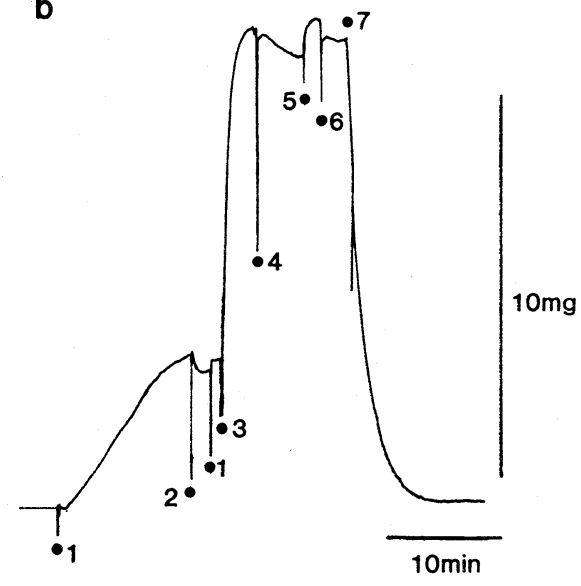

1. $\mathrm{Na} 10 \mathrm{mM} \mathrm{Ca} 3 \times 10^{-7} \mathrm{M} \quad$ 2. Na60mM Ca3X $10^{-7} \mathrm{M}$ 3. $\mathrm{Na} 10 \mathrm{mM} \mathrm{Ca} \times 10^{-6} \mathrm{M}$ $\begin{array}{lll}\text { 4. } \mathrm{Na} 60 \mathrm{mM} \mathrm{Ca} \times 10^{-6} \mathrm{M} & \text { 5. } \mathrm{Na} 10 \mathrm{mM} \mathrm{Ca} 10^{-5} \mathrm{M} & \text { 6. } \mathrm{Na} 60 \mathrm{mM} \mathrm{Ca} 10^{-5} \mathrm{M}\end{array}$ 7. wash

Fig. 5. A. The pCa and tension relationship observed in skinned muscle fibers. The tension produced by application of $10^{-5} \mathrm{M}$ free $\mathrm{Ca}$ was registered as a relative tension of 1.0 . Four different ionic compositions were used in the relaxing solution. B. Actual records of tension produced by various concentrations of free $\mathrm{Ca}$. Concentrations of $\mathrm{Na}$ and $\mathrm{Ca}$ were shown in the figure. In a, the contraction evoked by $118 \mathrm{~mm}[\mathrm{~K}]_{\mathrm{o}}$ from the intact muscle tissue served as the control. b shows the Ca-induced contraction of skinned fibers in various concentrations of $\mathrm{Ca}$ and $\mathrm{Na}$.

Vol. 31, No. 6, 1981 

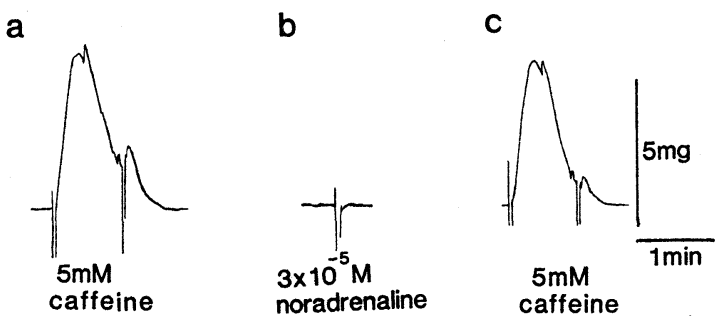

Fig. 6. Effects of noradrenaline $\left(3 \times 10^{-5} \mathrm{M}\right)$ on release of accumulated $\mathrm{Ca}$ from the store site in skinned muscle fibers. a, after procedures 1 and $2,5 \mathrm{~mm}$ caffeine was applied; $b, 3 \times$ $10^{-5} \mathrm{M}$ noradrenaline was applied instead of caffeine; $\mathrm{c}$, after control. The procedures were the same as those described in a.

The effects of excess $\mathrm{Na}$ solution on the caffeine-induced contraction in skinned muscles were observed. After the skinned fiber was left for $5 \mathrm{~min}$ in $10^{-4} \mathrm{M}$ EGTA-containing relaxing solution, $10^{-6} \mathrm{M}$ Ca with $10^{-4} \mathrm{M}$ EGTA-containing solution was applied to the tissue for $3 \mathrm{~min}$ (procedure 1) then the tissue was washed for $3 \mathrm{~min}$ with $10^{-4} \mathrm{M}$ EGTA-containing relaxing solution (procedure 2). After accumulation of $\mathrm{Ca}$ in the store site by the above procedures, $5 \mathrm{~mm}$ caffeine was applied to the tissue (procedure 3) and the amplitude of caffeineinduced contraction was compared in $10 \mathrm{~mm} \mathrm{Na}$ and $60 \mathrm{~mm} \mathrm{Na}$.

In skinned muscles, when the amplitude of caffeine-induced contractions in the presence of $60 \mathrm{mM} \mathrm{Na}$ was compared with that in $10 \mathrm{~mm} \mathrm{Na}$ during procedure $1(60 \mathrm{~mm} \mathrm{Na} / 10 \mathrm{~mm} \mathrm{Na})$, the amplitude ratio was $105.4 \pm 7.9 \%(n=7)$, and when $60 \mathrm{~mm} \mathrm{Na}$ was applied during procedure 2 or 3, the amplitude ratio was $97.9 \pm$ $4.9 \%(n=4)$ or $71.7 \pm 5.0 \%(n=4)$, respectively. During procedures 1 and 2 , when $60 \mathrm{~mm} \mathrm{Na}$ was added, the amplitude ratio was $98.3 \pm 3.3 \%(n=3)$. When $60 \mathrm{~mm} \mathrm{Na}$ was applied to the tissue throughout the experimental procedures $(1+$ $2+3)$, the amplitude ratio was reduced to $70.0 \pm 9.7 \%(n=5)$. These results indicate that accumulation of $\mathrm{Ca}$ in the store site is not affected by the presence of either $60 \mathrm{~mm}$ or $10 \mathrm{~mm} \mathrm{Na}$, but sensitivities of Ca-receptors to free $\mathrm{Ca}$ and $\mathrm{Ca}$ releasing sites to caffeine are suppressed in the presence of $60 \mathrm{~mm} \mathrm{Na}$ compared to those in $10 \mathrm{~mm} \mathrm{Na}$. The effects of $60 \mathrm{~mm} \mathrm{Na}$ on $\mathrm{Ca}$ accumulation and release from skinned fibers are summarized in Table 1.

Figure 6 shows the effects of NA on a skinned fiber. When NA $\left(3 \times 10^{-5} \mathrm{M}\right)$ instead of caffeine was applied to the tissue during procedure 3, no contraction was evoked. Furthermore, application of NA did not affect the caffeine-induced contraction, even when NA was applied during procedure 2 .

\section{DISCUSSION}

In $\mathrm{Ca}$-free solution, the $\mathrm{K}$ - and $\mathrm{NaCl}$-free-induced contractions in the guineapig mesenteric artery rapidly ceased, the NA-induced contraction ceased within 
Table 1. Effects of excess $\mathrm{Na}(60 \mathrm{~mm})$ on the caffeine-induced contraction in skinned muscle fibers. Excess $\mathrm{Na}$ was applied during the $\mathrm{Ca}$-accumulating process (procedure $1 ; 10^{-6} \mathrm{M} \mathrm{Ca}, 10^{-4} \mathrm{M}$ EGTA, and 60 or $10 \mathrm{mM} \mathrm{Na-containing} \mathrm{relaxing} \mathrm{so-}$ lution was applied for $3 \mathrm{~min}$ ), during the removal of free $\mathrm{Ca}$ (procedure $2 ; 10^{-4} \mathrm{M}$ EGTA and 60 or $10 \mathrm{~mm} \mathrm{Na-containing} \mathrm{solution} \mathrm{for} 3 \mathrm{~min}$ ) and during application of $5 \mathrm{~mm}$ caffeine (procedure 3). The values $(\%)$ are calculated from amplitudes of the caffeine-induced contraction with or without treatment of $60 \mathrm{~mm} \mathrm{Na}$. The amplitude of caffeine-induced contraction in the control ( $10 \mathrm{~mm} \mathrm{Na}$ in the relaxing solution) was registered as $100 \%$.

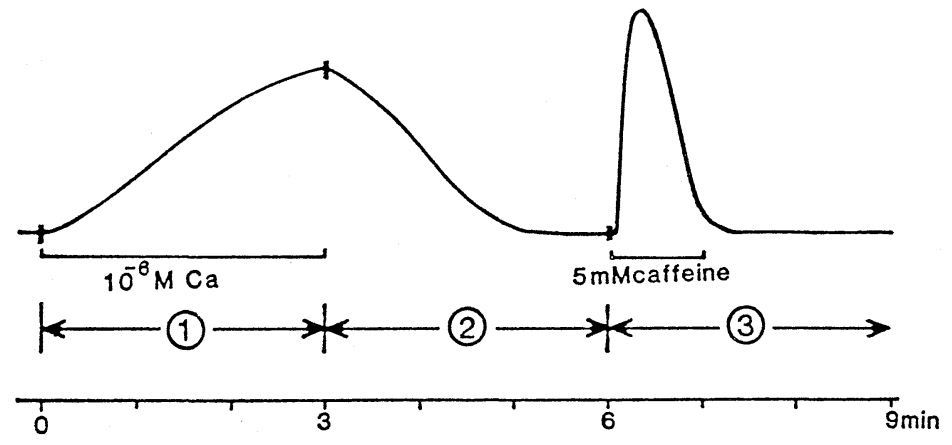

\begin{tabular}{|c|c|c|c|}
\hline $\begin{array}{l}\text { Procedure } 1 \\
\text { (mM Na) }\end{array}$ & $\begin{array}{l}\text { Procedure } 2 \\
(\mathrm{~mm} \mathrm{Na})\end{array}$ & $\begin{array}{l}\text { Procedure } 3 \\
(\mathrm{~mm} \mathrm{Na})\end{array}$ & $\%$ \\
\hline 10 & 10 & 10 & $(n=7)$ \\
\hline 60 & 10 & 10 & $105.9 \pm 7.9(n=7)$ \\
\hline 10 & 60 & 10 & $97.9 \pm 4.9(n=4)$ \\
\hline 10 & 10 & 60 & $71.7 \pm 5.0 \quad(n=4)$ \\
\hline 60 & 60 & 10 & $98.3 \pm 3.3(n=3)$ \\
\hline 60 & 60 & 60 & $70.0 \pm 9.7(n=5)$ \\
\hline
\end{tabular}

$5 \mathrm{~min}$ and the caffeine-induced contraction persisted for more than $15 \mathrm{~min}$. In $\mathrm{NaCl}$-free solution, caffeine and NA markedly enhanced the mechanical response. However, excess $[\mathrm{K}]_{0}$ produced a similar amplitude of phasic contraction with or without pretreatment with $\mathrm{NaCl}$-free solution. In both $118 \mathrm{~mm}[\mathrm{~K}]_{\circ}$ and $\mathrm{NaCl}-$ free solutions, concentrations of $[\mathrm{Na}]_{\text {。 }}$ were the same and therfore, the $118 \mathrm{~mm} \mathrm{~K}$ induced contraction following pretreatment in $\mathrm{NaCl}$-free solution probably produces the same amplitude as that observed without pretreatment. If indeed such is the case, the $\mathrm{K}$-induced contraction may be generated by a voltage-dependent $\mathrm{Ca}$ influx and a Na-deficiency-induced $\mathrm{Ca}$ influx.

In the guinea-pig taenia coli, the $\mathrm{Na}$ content in $\mathrm{Na}$-free solution decreased from $14 \mathrm{~mm}$ to nearly zero within $30 \mathrm{~min}$ at $37^{\circ} \mathrm{C}$ (BRADING et al., 1980) or to $90 \%$ depletion in the cell within $30 \mathrm{~min}$ (VAN BREEMEN et al., 1980). Various vascular smooth muscle cells had almost the same $\mathrm{Na}$ content as was detected in the taenia coli (rat aorta, $12 \mathrm{~mm}$; rat portal vein, $13 \mathrm{~mm}$; rabbit main pulmonary artery, 12 mM; rabbit portal vein, $26 \mathrm{~mm}$; review of JONES, 1980). The concentration of $[\mathrm{Na}]_{\mathrm{i}}$ used in the case of these vascular muscles was the same as that used in the 
relaxing solution to prepare the skinned muscle, in the present experiments.

In skinned muscles of the mesenteric artery, increase in the $\mathrm{Na}$ concentration from 10 to $60 \mathrm{~mm}$ had no effect on the accumulation of $10^{-6} \mathrm{M} \mathrm{Ca}$, yet excess $\mathrm{Na}$ solution inhibited the $\mathrm{Ca}$-releasing site and the $\mathrm{Ca}$ receptor of contractile protein by $30 \%$. However, reduction in the $\mathrm{Ca}$ sensitivity was less in the presence of free $\mathrm{Ca}$ in concentrations over $10^{-5} \mathrm{M}$. In the ranges of 10 and $30 \mathrm{~mm} \mathrm{Na}$, however, no difference was observed in the action on the Ca-receptor, and Ca-releasing mechanism. The property of the saponin-treated chemically skinned muscles of the guinea-pig mesenteric artery was discussed by Ітон et al. (1981) in relation to observations reported in the case of the hog coronary artery (FILO et al., 1965), the rabbit pulmonary artery (ENDO et al., 1977) and the guinea-pig taenia coli (SAIDA and Nonomura, 1978). Under treatment with saponin, the internal structures (mainly sarcoplasmic reticulum) and the Ca receptor of the contractile protein are functionally preserved for measurements of the Ca-releasing ability and superprecipitation of myosin B (SAIDA and NoNOMURA, 1978).

If $[\mathrm{Na}]_{\mathrm{i}}$ remains much the same in Krebs and $\mathrm{NaCl}$-free solution (10-30 mM), the $\mathrm{Ca}$ receptor of the contractile protein may not be affected, as observed in skinned muscles. However, when $[\mathrm{Na}]_{i}$ in the $\mathrm{NaCl}$-free solution is reduced to less than $10 \mathrm{~mm}$, it is uncertain whether or not the sensitivity of the Ca receptors remains the same. Reduction of $\mathrm{Na}$ below $10 \mathrm{~mm}$ by replacement of $\mathrm{Na}_{2}$-ATP with $\mathrm{K}_{2}$-ATP was not done due to instability of $\mathrm{K}_{2}$-ATP. In $\mathrm{NaCl}$-free solution (15 mM Na-containing solution), a large contraction was evoked (0.8 times the $118 \mathrm{~mm}[\mathrm{~K}]_{\mathrm{o}}$-induced contraction), therefore, the $\mathrm{NaCl}$-free-induced contraction may be due to increase in the free $\mathrm{Ca}$ in the cell rather than increase in the sensitivity of the Ca receptor.

REUTER et al. (1973) reported that in the case of the rabbit aorta, the Na concentration gradient across the cell membrane was a determinant of $[\mathrm{Ca}]_{\mathrm{i}}$ and measurement of the $\mathrm{Ca}$ efflux into the solution containing various concentrations of $[\mathrm{Na}]_{0}$ revealed a coupling between $\mathrm{Na}$ and $\mathrm{Ca}$ ions in this vascular muscle cell. BLAUSTEIN (1977) postulated that by equating the electrochemical gradient for $\mathrm{Na}$ and $\mathrm{Ca}, 3 \mathrm{Na}$ would be required to move $1 \mathrm{Ca}$. Furthermore, the Na-influx and Ca-efflux exchange process is capable of reversal to a Na-efflux and Ca-influx exchange process, under modified ionic environments. BRADING and WIDDICOMBE (1976) found that a fraction of the Ca influx into the taenia coli was dependent on $[\mathrm{Na}]_{i}$, and a component of $\mathrm{Ca}$ efflux was dependent on $[\mathrm{Na}]_{\circ}$. This idea was supported by the findings of Hirata et al. (1980). RAEYMAEKER et al. (1974) did not find a consistent slowing of $\mathrm{Ca}$ efflux when $\mathrm{Li}$ or choline was substituted for $\mathrm{Na}$. VAN BREEMEN et al. (1973), WeIss (1977), and VAN BREEMEN et al. (1980) considered that only a part of the $\mathrm{Ca}$ exchange can be explained by this Na-Ca exchange mechanism and that the main mechanism of the generation of contraction is related to the suppression of the Ca-Mg ATPase transport system which reduces $[\mathrm{Ca}]_{i}$. In the case of this mechanism, the sarcoplasmic reticulum would be functionally 
coupled with the sarcolemma directly (VAN BREEMEN et al., 1980; BRADING et al., 1980; Jones, 1980). The Ca-stimulated Mg ATPase is located mainly in the sarcoplasmic reticulum but not or only in part, in the sarcolemma (HESS and FoRD, 1974; SloANe, 1980). WeI et al. (1976) and DANiEL et al. (1977) reported that the isolated membrane fraction from the rat myometrium (70-80\% sarcolemma and $20 \%$ sarcoplasmic reticulum) can accumulate $\mathrm{Ca}$. However, they stated that the possible contribution of the sarcoplasmic reticulum contaminated in the fraction had to be considered.

Although we have no data to support the idea that increase in $[\mathrm{Ca}]_{i}$ in the $\mathrm{NaCl}$-free solution is due to suppression of the $\mathrm{Ca}$ pump, the $\mathrm{Na}-\mathrm{Ca}$ exchange diffusion, or to increase in the $\mathrm{Ca}$ influx on the plasma membrane, nevertheless, the large phasic contraction and marked accumulation of $\mathrm{Ca}$ in the store site in the $\mathrm{NaCl}$-free solution do favour the idea that the $\mathrm{Ca}$ influx occurs through the $\mathrm{Na}$ channel, under conditions in which $[\mathrm{Na}]_{\mathrm{o}}$ levels are low, as has been postulated in the case of the rabbit ear artery (Droogmans and CASTEels, 1979). The supporting evidence is: 1) The $\mathrm{NaCl}$-free-induced contraction was composed of phasic and tonic components, and the velocity of phasic tension development was much the same as that observed during the K-induced contraction. This rapid velocity of tension development is too fast to be accounted for by the retention of $\mathrm{Ca}$ due to suppression of the $\mathrm{Ca}$ efflux. Furthermore, the minimum reduction in $[\mathrm{Na}]_{\text {o }}$ required to produce the contraction was $108 \mathrm{~mm}[\mathrm{Na}]_{0}$, and this amount of $[\mathrm{Na}]_{0}$ would probably not reverse the $\mathrm{Na}-\mathrm{Ca}$ exchange process from $\mathrm{Na}$ influx to efflux. Moreover, in K-free solution, smooth muscles of the mesenteric artery generated contraction due to accumulation of $[\mathrm{Ca}]_{i}$ as a consequence of increased $[\mathrm{Na}]_{i}$. However, development of the contraction required a very long latency after replacement with K-free solution (Suzuki and KuriYamA, 1980). 2) Diltiazem (a $\mathrm{Ca}$ channel blocker or $\mathrm{Ca}$ antagonist) suppressed the K-induced and NA-induced contractions in the mesenteric artery, but the contraction evoked in $\mathrm{NaCl}$-free solution was not suppressed (Suzuki et al., 1981). This means that the Ca influx appearing in the $\mathrm{NaCl}$-free solution may not utilize the $\mathrm{Ca}$ channel, at the plasmic membrane.

Finally, the contraction evoked in $\mathrm{NaCl}$-free solution in the guinea-pig mesenteric artery is not a typical example of general features of vascular smooth muscles, e.g., in the porcine coronary artery, the tissue did not contract in $\mathrm{NaCl}$ free or Na-free solution (Hirata et al., 1980). Regional and species differences in vascular smooth muscle tissues probably account for such differences.

This work was supported by the Ministry of Education and Welfare of Japan $(54408,544020$, 577111) and Yamada Science Foundation. We thank M. Ohara for reading the manuscript.

\section{REFERENCES}

Blaustein, M. P. (1977) Effects of internal and external cations and of ATP on sodium-calcium and calcium-calcium exchange in squid axons. Biophys. J., 20: 79-111.

Vol. 31, No. 6, 1981 
Bolton, T. B. (1979) Mechanisms of action of transmitters and other substances in smooth muscle. Physiol. Rev., 59: 606-718.

Brading, A. F., Barnett, M., and Sneddon, P. (1980) The effect of sodium removal on the contractile responses of the guinea-pig taenia coli to carbachol. J. Physiol. (Lond.), 306: 411-420.

Brading, A. F. and Widdicombe, J. H. (1976) Interaction between sodium and calcium movements in smooth muscle. In: Colloquium on Smooth Muscle, Pharmacology and Physiology, ed. by Worcel, M. and VASSORT, G. INSERM, Paris, pp. 235-245.

BüLBRING, E. (1954) Membrane and potentials of smooth muscle fibres of taenia coli of the guinea-pig. J. Physiol. (Lond.), 125: 302-315.

Casteels, R., Kitamura, K., Kuriyama, H., and Suzuki, H. (1977) The membrane properties of the smooth muscle cells of the rabbit main pulmonary artery. J. Physiol. (Lond.), 271: 41-61.

Daniel, E. E., Kwan, C. Y., Matlib, M. A., Crankshaw, D., and Kidwai, A. (1977) Characterization and $\mathrm{Ca}^{2+}$-accumulation by membrane fractions from myometrium and artery. In: Excitation-Contraction Coupling in Smooth Muscle, ed. by CASTEELS, R., Godfraind, T., and RÜEGG, J. C. Elsevier/North-Holland, Amsterdam, New York, pp. 181-188.

Droogmans, G. and CASteEls, R. (1979) Sodium and calcium interactions in vascular smooth muscle cells of the rabbit ear artery. J. Gen. Physiol., 74: 57-70.

Endo, M. (1977) Calcium release from the sarcoplasmic reticulum. Physiol. Rev., 57: 71-108.

Endo, M., Kitazawa, S., Yagi, M., IIno, M., and Kakuta, Y. (1977) Some properties of chemically skinned smooth muscle fibers. In: Excitation-Contraction Coupling in Smooth Muscle. ed. by Casteels, R., Godfraind, T., and RüEGG, J. C. Elsevier/North Holland, Amsterdam, New York, pp. 199-209.

FiLo, R. S., BoHr, D. F., and RüEGG, J. C. (1965) Glycerinated skeletal and smooth muslce: calcium and magnesium dependence. Science, 147: 1581-1583.

Friedman, S. M. (1977) The effects of external sodium substitution on cell sodium and potassium in vascular smooth muscle. J. Physiol. (Lond.), 270: 195-208.

Hess, M. L. and Ford, G. D. (1974) Calcium accumulation by subcellular fraction from vascular smooth muscle. J. Mol. Cell. Cardiol., 6: 275-282.

Hirata, M., ItoH, T., and KuriYama, H. (1980) Effect of external cations of calcium efflux from single cells of the guinea-pig taenia coli and porcine coronary artery. J. Physiol. (Lond.), 310: 321-336.

Itoh, T., KuriYama, H., and Suzuki, H. (1981) Excitation-contraction coupling mechanism in the guinea-pig mesenteric artery. J. Physiol. (Lond.), in press.

Jones, A. W. (1980) Content and fluxes of electrolytes. In: Handbook of Physiology, Sec. 2, Circulation, Vol. 2, Vascular Smooth Muscle, ed. by BoHr, D., SomLyo, A. P., and Sparks, H., Jr. The Am. Physiol. Soc., Baltimore, pp. 259-299.

KATASE, T. and TomitA, T. (1972) Influences of sodium and calcium on the recovery process from potassium contracture in the guinea-pig taenia coli. J. Physiol. (Lond.), 224: 489-500.

Kuriyama, H. and Suzuki, H. (1981) Adrenergic transmissions in the guinea-pig mesenteric artery and their cholinergic modulations. J. Physiol. (Lond.), 317: 383-396.

Martell, A. E. and Schwarzenbach, G. (1956) Adenosinphosphate und Triphosphate als Komplexbildner für Calcium und Magnesium. Helv. Chim. Acta, 39: 653-666.

RAeymaeKer, L., WuytaCK, F., and CASTEels, R. (1974) Na-Ca exchange in taenia coli of the guinea-pig. Pflügers Arch., 347: 329-340.

Reuter, H., Blaustein, M. P., and Haeusler, G. (1973) Na-Ca exchange and tension development in arterial smooth muscle. Philos. Trans. R. Soc. Lond. (Biol.), 265: 87-94.

SAIDA, K. and Nonomura, Y. (1978) Characteristics of $\mathrm{Ca}^{2+}-$ and $\mathrm{Mg}^{2+}$-induced tension development in chemically skinned smooth muscle fibers. J. Gen. Physiol., 72: 1-14. 
SLOANE, B. F. (1980) Isolated membranes and organelles from vascular smooth muscle. In: Handbook of Physiology, Sec. 2, Circulation, Vol. 2, Vascular Smooth Muscle, ed. by BoHr, D., Somlyo, A. P., and Sparks, H., Jr. The Am. Physiol. Soc., Baltimore, pp. 121-132.

Suzuki, H., IToH, T., and KuRIYAMA, H. (1981) Effects of diltiazem on the mesenteric artery of guinea-pig. Proc. J. Pharmacol. Soc., Annu. Gen. Meeting, in press.

SuzUKI, H. and KuRIYAMA, H. (1980) Observation of quantal release of noradrenaline from vascular smooth muscles in potassium-free solution. Jpn. J. Physiol., 30: 665-670.

Van Breemen, C., Aaronson, P., and Loutzenhiser, R. (1978) Sodium-calcium interactions in mammalian smooth muscle. Pharmacol. Rev., 30: 167-208.

Van Breemen, C., Aaronson, P., Loutzenhiser, R., and Meisheri, K. (1980) $\mathrm{Ca}^{2+}$ movements in smooth muscle. Chest (Suppl.), 78: 157-165.

Van Breemen, C., Farinas, B. R., Casteels, R., Gerba, P., Wuytack, F., and Deth, R. (1973) Factors controlling cytoplasmic $\mathrm{Ca}^{2+}$ concentration. Philos. Trans. R. Soc. Lond. (Biol.), 265: $57-71$.

Wei, J. W., JANIS, R. A., and Daniel, E. E. (1976) Studies on subcellular fractions from mesenteric arteries of spontaneously hypertensive rats: Alterations in both calcium uptake and enzyme activities. Blood Vessels, 13: 293-308.

WeIss, G. B. (1977) Calcium and contractility in vascular smooth muscle. In: Advances in General and Cellular Pharmacology, Vol. 2, Chap. 2, ed. by Narahashi, T. and Bianchi, C. P. New York, Plenum, pp. 71-154. 